\title{
Histone acetyltransferase inhibitor II induces apoptosis in glioma cell lines via the p53 signaling pathway
}

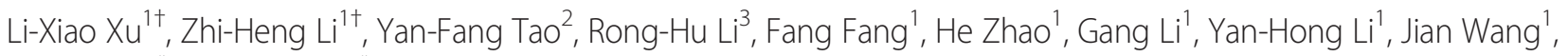
Xing Feng ${ }^{3^{*}}$ and Jian Pan $^{2^{*}}$

\begin{abstract}
Background: Histone acetyltransferase (HAT) inhibitors can inhibit proliferation and induce apoptosis in cancer cell lines. The novel cell-permeable p300/CREB-binding protein (CBP)-selective HAT inhibitor HATi II can reduce histone H3 acetylation and induce chromatin condensation in HeLa cells. Here, we examined the effects and mechanism of action of HATi II in glioma cell lines.

Methods: Cell viability was assessed using the CCK-8 assay. Cell cycle analysis was performed using flow cytometry. Apoptosis was evaluated using Annexin V staining and flow cytometry, Hoechst 33342 staining and the TUNEL assay. Expression and cleavage of caspase-3, caspase-9 and poly ADP-ribose polymerase (PARP) were assessed by Western blotting. Statistical analysis was performed using two-tailed Student's t-tests. The gene expression profiles of U251 glioma cells treated with HATi II or DMSO were analyzed using the Arraystar Human $8 \times 60 \mathrm{~K}$ LncRNA/ mRNA expression array; data was analyzed using MEV (Multi Experiment View) cluster software. Datasets representing genes with altered expression profiles ( $\geq 2$-fold) derived from the cluster analyses were subjected to gene ontology and pathway analysis.
\end{abstract}

Results: HATi II inhibited the proliferation of U251, U87, HS683 and SHG44 cells in a dose-dependent manner. HATi II induced cell cycle arrest at the G2/M phase, and induced significant levels of apoptosis, apoptotic body formation and DNA fragmentation in HATi II-treated U251 and SHG44 cells. HATi II induced cleavage of caspase-3, caspase-9 and PARP in U251 and SHG44 cells. In HATi II-treated U251 cells, 965 genes were upregulated, 984 genes were downregulated and 3492/33327 IncRNAs were differentially expressed. GO analysis showed the differentially expressed genes with known functions are involved in a variety of processes; alcoholism, p53 signaling pathway, cytokine-cytokine receptor interaction and transcriptional mis-regulation in cancer were the four most significant pathways. Upregulation of p53 signaling pathway-related genes in HATi Il-treated cells was confirmed by quantitative RT-PCR and Western blotting.

Conclusions: HATi II inhibits proliferation and induces apoptosis via the caspase-dependent pathway in human glioma cell lines, possibly by activating the p53 signaling pathway. HATi II deserves further investigation as a novel treatment for glioma.

Keywords: HATi II, Glioma, Apoptosis, LncRNA/mRNA, p53 signaling pathway

\footnotetext{
*Correspondence: xing_feng66@hotmail.com; panjian2008@163.com

${ }^{\dagger}$ Equal contributors

${ }^{3}$ Department of Neonatology, Children's Hospital of Soochow University,

Suzhou 215006, China

${ }^{2}$ Department of Hematology and Oncology, Children's Hospital of Soochow

University, Suzhou 215006, China

Full list of author information is available at the end of the article
}

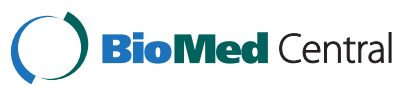

(c) 2015 Xu et al.; licensee BioMed Central. This is an Open Access article distributed under the terms of the Creative Commons Attribution License (http://creativecommons.org/licenses/by/4.0), which permits unrestricted use, distribution, and reproduction in any medium, provided the original work is properly credited. The Creative Commons Public Domain Dedication waiver (http://creativecommons.org/publicdomain/zero/1.0/) applies to the data made available in this article, unless otherwise stated. 


\section{Introduction}

Gliomas are the most common type of primary brain tumor in adults and second most common childhood malignancy after leukemia $[1,2]$. The annual incidence of glioma is approximately 3-8 per 10 million [3]. According to the histopathological and clinical criteria established by the World Health Organization (WHO), gliomas can be grouped into four grades I-IV [4], and there are three principal types of glioma: astrocytomas, oligodendrogliomas and oligoastrocytomas. Despite recent advances in surgical resection, chemotherapy and radiotherapy, the prognosis of patients with glioma continues to be very poor; the five-year overall survival rate for glioma is less than $10 \%$ [5] and is the third lowest of all cancers after pancreatic and lung cancer [6-8].

Current standard therapies for newly-diagnosed glioma include surgical resection followed by adjuvant radiotherapy and/or chemotherapy [9]. Nevertheless, surgical resection is often limited by a lack of a clear primary tumor margin and by the location of the tumor close to vital anatomical structures. Moreover, the effectiveness of radiotherapy and chemotherapy is suboptimal in many cases, largely due to the rapid development of tumor cell resistance to radiation and chemotherapeutic drugs. In addition, the blood-brain barrier and side-effects limit the effectiveness of chemotherapy drugs. Clinicians are eager to find novel, more specific therapeutic options with fewer sideeffects for glioma; small-molecule inhibitors of molecular targets may be promising candidate drugs.

Recent data has strongly indicated that alterations at the histone level may play a role in glioma tumorigenesis. Histone acetylation is one of the most well-characterized epigenetic modifications and is controlled by histone acetyltransferases (HATs) and histone deacetylases (HDACs) [10]. HATs play a central role in the modification of chromatin to create a favorable environment for a number of important cellular processes [11]. Acetylation neutralizes the positive charge on lysine residues and thereby weakens the bond between DNA and histone tails. Thus, histone acetylation is linked to transcriptional activation, whereas deacetylation is generally associated with transcriptional repression. Deletions or inactivating mutations in multiple genes encoding HATs have been associated with oncogenesis and tumor progression; these mutations alter the transcription of genes that regulate key functions such as proliferation, cell cycle progression and apoptosis [12,13]. Numerous genetic studies have also indicated that HATs are important factors linked to a variety diseases, including cancer $[14,15]$.

Enzymes that catalyze the reversible post-translational modification of histones on lysine residues by acetylation and methylation have received attention as potential drug targets in cancer and other diseases. A recent study found that a variety of small-molecule inhibitors which target
HATs could affect cell proliferation and induce tumor cell growth arrest, apoptosis and differentiation in prostate cancer and neuroblastoma cell lines [16-18]. The effects of HATs on cellular physiology and disease could potentially be ameliorated via the use of specific pharmacological inhibitors.

Very few specific HAT inhibitors have been identified; however, several compounds with HAT-inhibitory activity were recently identified. Interestingly, some of these compounds have been shown to inhibit the growth of cancer cells [19]. Anacardic acid, isolated from cashew nut shell liquid, was identified as a potent non-competitive inhibitor of both p300 and p300/CBP-associated factor (PCAF) HAT activity in vitro [20]. Quinoline was reported to promote tumor cell apoptosis in human leukemia cell lines by inhibiting p300 HAT activity [21]. Another p300/ CBP HAT inhibitor compound, C646, could inhibit the growth of both human melanoma and non-small-cell-lung (NSCL) cancer cell lines [22], and also could inhibit the growth of primary blasts isolated from patients with $\mathrm{t}$ $(8 ; 21)$-positive acute myelocytic leukemia (AML) as well as Kasumi-1 cells [23].

Histone acetyltransferase inhibitor II (HATi II) is a novel cell-permeable bis-arylidene cyclohexanone compound that acts as a p300/CBP-selective HAT inhibitor, which can reduce histone $\mathrm{H} 3$ acetylation and induce chromatin condensation in HeLa cells. The p300 protein is a transcriptional co-activator with intrinsic HAT activity that plays a crucial role in cell cycle progression, differentiation and apoptosis. Inhibition of p300 suppresses the cellular growth of melanoma cells [24] and induces apoptosis in prostate cancer cells [25]. P300 activity is also required for the G1/S transition in cancer cells [26,27]. Despite the fact that the anti-tumor effects of p300 inhibitors have been reported in other cancers, the effect of inhibiting p300 has not been extensively investigated in glioma cells. In the present study, we examined the molecular function of HATi II in glioma cell lines, and observed that HATi II can inhibit proliferation and induce cellular apoptosis via the caspase-dependent apoptotic pathway. In addition, microarray analysis and quantitative real-time PCR indicated that HATi II activates the p53 signaling pathway in glioma cells. These results suggest that HATi II may represent a novel target for therapy for patients with glioma.

\section{Materials and methods Reagents}

HATi II was purchased from Calbiochem (Billerica, MA, USA) and dissolved in DMSO (Sigma-Aldrich, St. Louis, MO, USA). The Cell Counting Kit-8 was obtained from Dojindo Laboratories (Kumamoto, Japan); 4,6-diamidino2-phenylindole (DAPI) and Hoechst 33342 were purchased from Sigma-Aldrich. Mouse monoclonal antibody against 
$\beta$-actin and rabbit polyclonal antibodies against caspase-3, caspase-9, PARP, PTEN and CDK1 were purchased from Cell Signaling Technology (Beverly, MA, USA); Reprimo, RRM2, CCNE2 and SFN from Boster (Wuhan, China); and p53 and p21 from Beyotime (Jiangsu, China). Anti-mouse and anti-rabbit peroxidase conjugated secondary antibodies were purchased from Pierce (Madison, WI, USA).

\section{Cell culture}

The glioma cell lines U251, U87, HS683 and SHG44 were obtained from the Cell Bank of the Chinese Academy of Sciences (Shanghai, China). The cells were maintained in DMEM (Invitrogen Life Technologies, Paisley, UK) containing 10\% fetal bovine serum (FBS; Hyclone, UT, USA) at $37^{\circ} \mathrm{C}$ in $5 \% \mathrm{CO}_{2}$. The cells were confirmed to be free from mycoplasma every three months using a commercially available kit (Invitrogen, Shanghai, China). All of the researchers who contributed to this study received standard cell culture training to prevent cell cross-contamination. The study was approved by the Ethics Committee of Children's Hospital of Soochow University.

\section{Cell proliferation and viability assays}

Glioma cells $\left(2 \times 10^{4}\right)$ were seeded in 96-well plates, cultured overnight, and then incubated with DMSO or varying concentrations of HATi II $(2.5,5$, 7.5, 10, 12.5, 15, 17.5, 20 or $25 \mu \mathrm{M}$ ) for $48 \mathrm{~h}$; the same volume of DMSO was added to the vehicle-treated wells as the drug-treated wells, and each drug concentration was tested in three replicate wells. Then, $10 \mu \mathrm{L}$ CCK8 solution (DOJINDO, Shanghai) was added to each well, incubated at $37^{\circ} \mathrm{C}$ for $4 \mathrm{~h}$ and the optical density (OD) values were measured at $450 \mathrm{~nm}$ using a scanning multi-well spectrophotometer. The survival rate of the treated cells was calculated relative to the control group. Cell proliferation was calculated as a percentage of the DMSO-treated control wells; $\mathrm{IC}_{50}$ values were derived after plotting the proliferation values on a logarithmic curve.

\section{Western blot analysis}

Glioma cells were harvested, washed and lysed using $1 \mathrm{x}$ RIPA buffer. Protein concentrations were determined using the BCA protein assay kit. Equal amounts of protein from the cell lysates were separated on 10\% SDS polyacrylamide gels and transferred onto polyvinylidene fluoride membranes. Membranes were blocked with 5\% non-fat milk in TBST and incubated with primary antibodies against caspase 3, caspase 9, PARP, PTEN, CDK1, Reprimo, RRM2, CCNE2 and SFN at $4^{\circ} \mathrm{C}$ overnight. Then, the membranes were washed and incubated with secondary antibodies against rabbit or mouse IgG conjugated to horseradish peroxidase (Cell Signaling) for $1 \mathrm{~h}$, then washed and the bands were visualized using chemiluminescence (ECL, Amersham-Pharmacia, Uppsala, Sweden); $\beta$-actin was used as an internal loading control. The expression of the target proteins relative to $\beta$-actin was used as a semi-quantitative comparison between different groups.

\section{Cell cycle assays}

Cells were seeded in 6-well plates $\left(1 \times 10^{6}\right.$ cells/well). HATi II stock solution (10 $\mathrm{mM}$ in anhydrous DMSO) was directly added to the culture media to achieve the desired concentrations; the volume of DMSO was kept constant at $0.1 \%$. After treatment with HATi II or DMSO for 24 or $48 \mathrm{~h}$, the cells were harvested and subjected to the following assays. For the cell cycle assay, the cells were washed twice with ice cold PBS, fixed in $70 \%$ ethanol at $4^{\circ} \mathrm{C}$ overnight, incubated with $10 \mathrm{mg} / \mathrm{mL}$ RNase A (SigmaAldrich) at $37^{\circ} \mathrm{C}$ for $30 \mathrm{~min}$, and then incubated with $50 \mathrm{mg} / \mathrm{mL}$ propidium iodide (Sigma-Aldrich). Cell cycle distribution was assessed by flow cytometry (FC500, Beckman Coulter, FL, USA).

\section{Cell apoptosis assays}

Apoptosis assays were conducted using the BD Annexin V Staining Kit (BD Biosciences, Franklin Lakes, USA) according to the manufacturer's instructions. Briefly, the cells were washed twice with cold PBS, resuspended in $1 \times$ Binding Buffer at a concentration of $\sim 1 \times 10^{6}$ cells $/ \mathrm{ml}$, $100 \mu \mathrm{l}$ of the cell suspension $\left(\sim 1 \times 10^{5}\right.$ cells $)$ was transferred to a $5 \mathrm{ml}$ culture tube, $5 \mu \mathrm{l}$ Annexin $\mathrm{V}$ and PI were added, the cells were gently mixed, incubated for $15 \mathrm{~min}$ in the dark at RT, $400 \mu \mathrm{l}$ of $1 \times$ Binding Buffer was added to each tube, and the cells were immediately analyzed by flow cytometry (within $1 \mathrm{~h}$ ).

\section{Hoechst 33342 staining analysis}

Cells were seeded into 6-well plates, and then treated with HATi II and cultured at $37^{\circ} \mathrm{C}$ for different periods of time, stained with $0.1 \mu \mathrm{g} / \mathrm{ml}$ Hoechst 33342 (Sigma) for $5 \mathrm{~min}$, then observed by fluorescence microscopy using appropriate filters for blue fluorescence.

\section{TUNEL assay}

DNA double-strand breaks occur late in the apoptotic pathway and were assessed using the TUNEL Apoptosis Detection Kit (Cat: KGA704; Kengent, Nanjing, China). Firstly, the cells were seeded on coverslips, treated with $10 \mu \mathrm{mol} / \mathrm{L} \mathrm{HATi}$ II for $48 \mathrm{~h}$, washed, fixed and stained as per the manufacturer's instructions, and the cell nuclei were stained with $1 \mu \mathrm{g} / \mathrm{mL}$ 4',6-diamidino-2-phenylindole (DAPI). Apoptotic cells were observed by laser scanning confocal microscopy (OLYMPUS IX71) at an excitation wavelength of 515-565 $\mathrm{nm}$. 


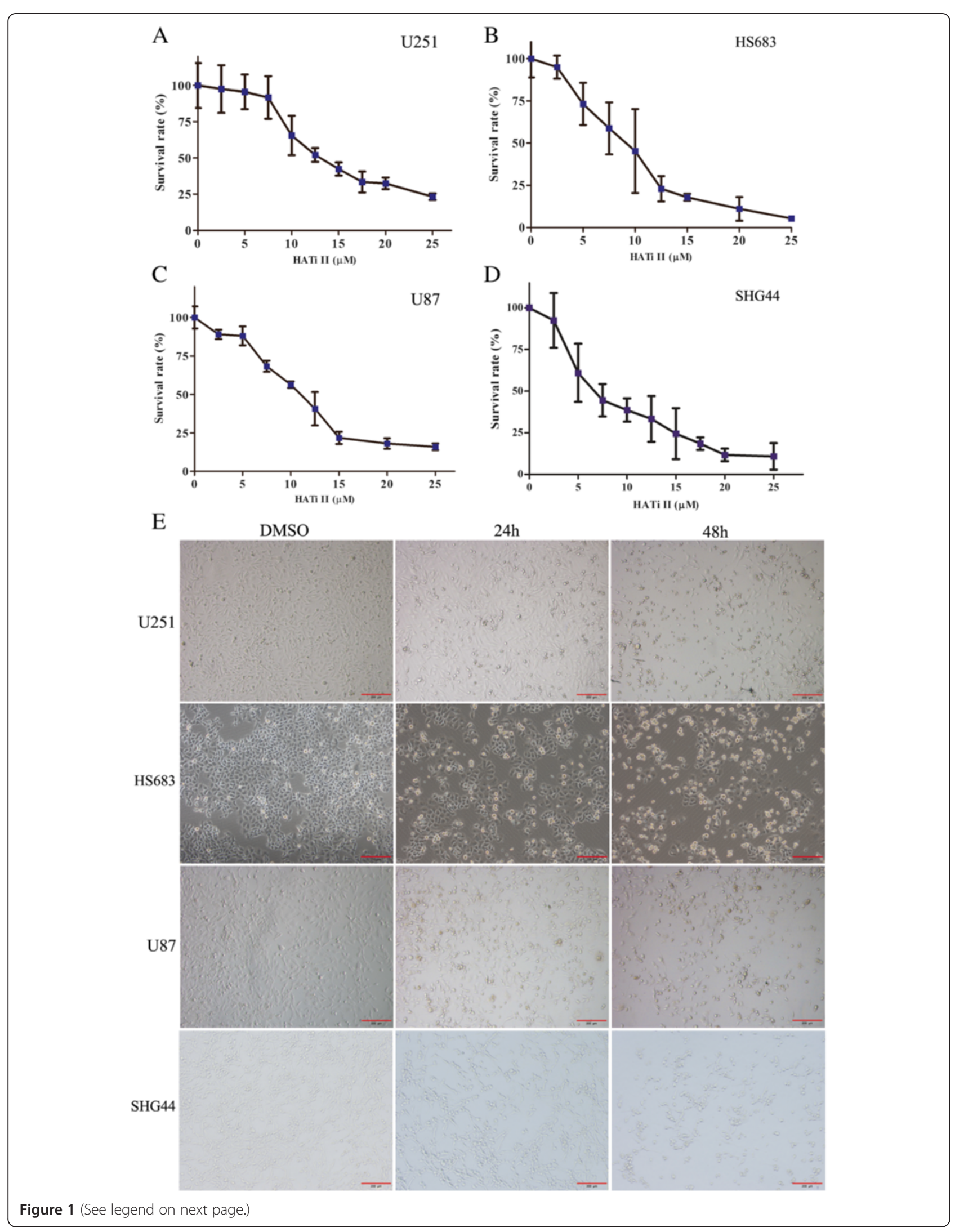


(See figure on previous page.)

Figure 1 Growth inhibitory effects of HATi II in glioma cell lines. (A-D) Cell viability assay. Glioma cells cultured in 96-well plates were treated with different concentrations of HATi II or DMSO for $48 \mathrm{~h}$, and cell viability was determined using the CCK-8 assay. Cell proliferation was calculated as a percentage of the DMSO-treated control cells; IC50 values were derived by plotting the proliferation values on a logarithmic curve. The experiments were repeated three times. (E) Phase-contrast microscopy of U251, HS683, U87 and SHG44 cells treated with HATi II for 24 or 48 h ( $\times 100$ ).

\section{RNA extraction, RNA quality control and microarray hybridization}

Total RNA was extracted from the cells using the singlestep TRIzol RNA extraction kit (Invitrogen, CA, USA) according to the manufacturer's instructions, concentrated by isopropanol precipitation and column-purified using the Qiagen RNeasy Mini Kit (Cat No. 74104). The integrity and concentration of the RNA samples were assessed prior to labeling; RNA was quantified and assessed using a NanoDrop ND-1000 (Thermo Scientific), RNA integrity was assessed using denaturing agarose gel electrophoresis. The Quick Amp Labeling Kit (Agilent Technologies) was used for sample labeling and hybridization to Arraystar_Human_LncRNA_8 × 60 k v3.01 microarrays was performed in Agilent Sure Hyb Hybridization Chambers.

\section{Data collection, normalization and analysis}

After washing, the hybridized microarrays were scanned using an Agilent DNA Microarray Scanner and data was extracted using Agilent Feature Extraction software. Quantile normalization and subsequent data processing were performed using the GeneSpring GX v12.0 software package (Agilent Technologies). After quantile normalization of the raw data, mRNAs that had 'Present' or 'Marginal' flags in at least one out of two samples were selected for differentially expressed mRNA screening. To identify differentially expressed mRNAs, we performed

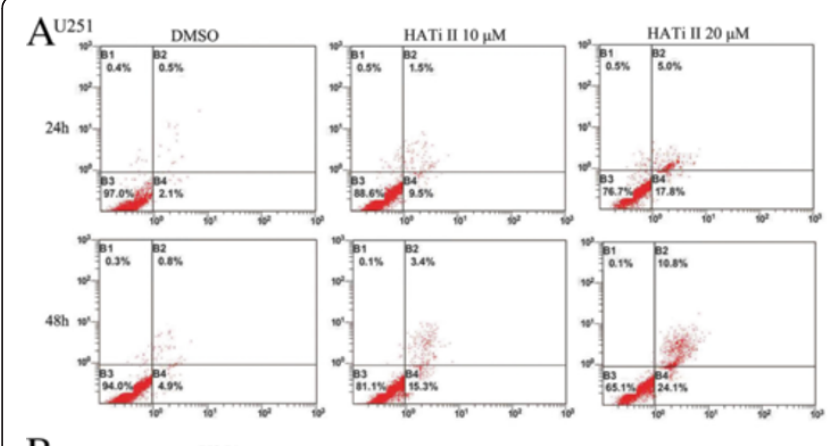

B
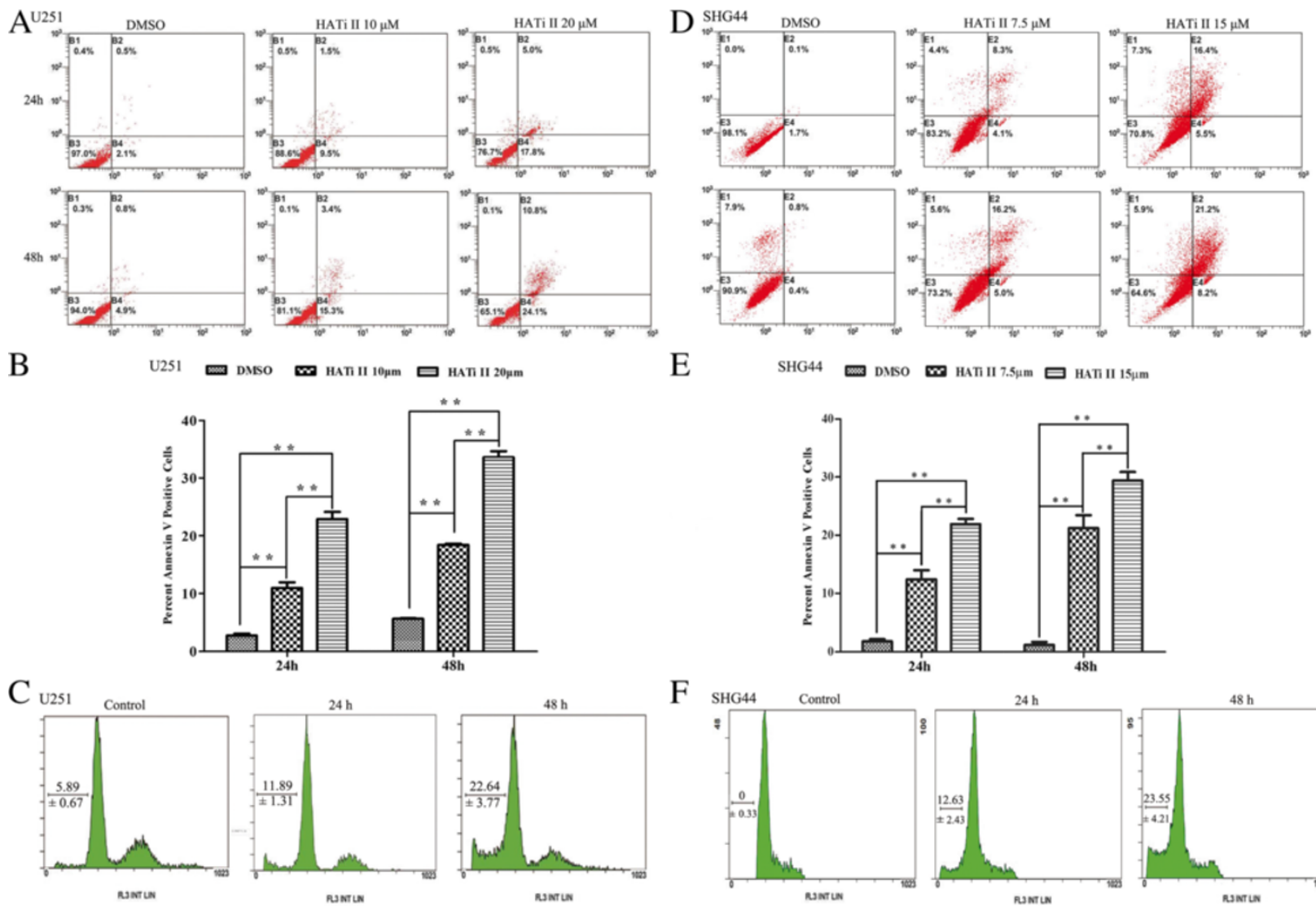

E

SHG44 DMso

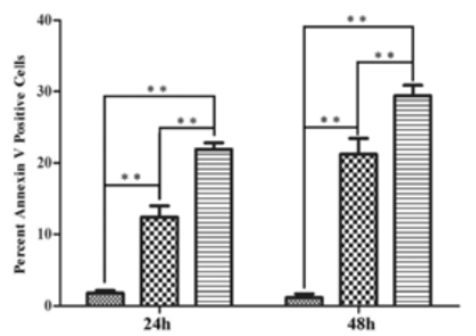

F

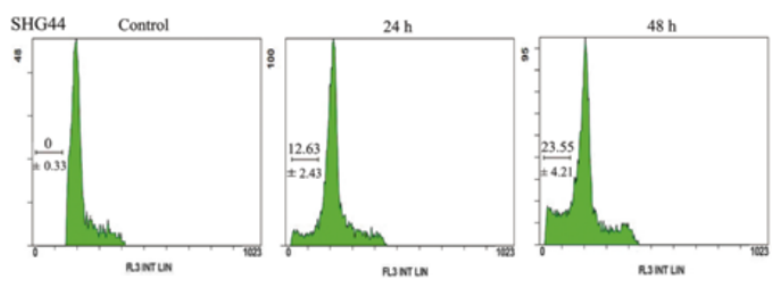

Figure 2 HATi II induces apoptosis in glioma cell lines. (A-C) U251 cells or (D-F) SHG44 cells were treated with HATi II for 24 or 48 h and apoptosis was determined by Annexin V-FITC/PI dual labeling and flow cytometry (A, D), and the numbers of Annexin V (+) and PI (-)\% cells were quantified (B, E); ${ }^{*} p<0.05$ or ${ }^{* *} p<0.01$ compared with DMSO-treated control cells. (C, F) Cell cycle analysis of U251 and SHG44 cells treated with HATi II for 24 or 48 h; DNA fragmentation was observed after $24 \mathrm{~h}$ and increased in a time-dependent manner. These analyses were repeated three times. 


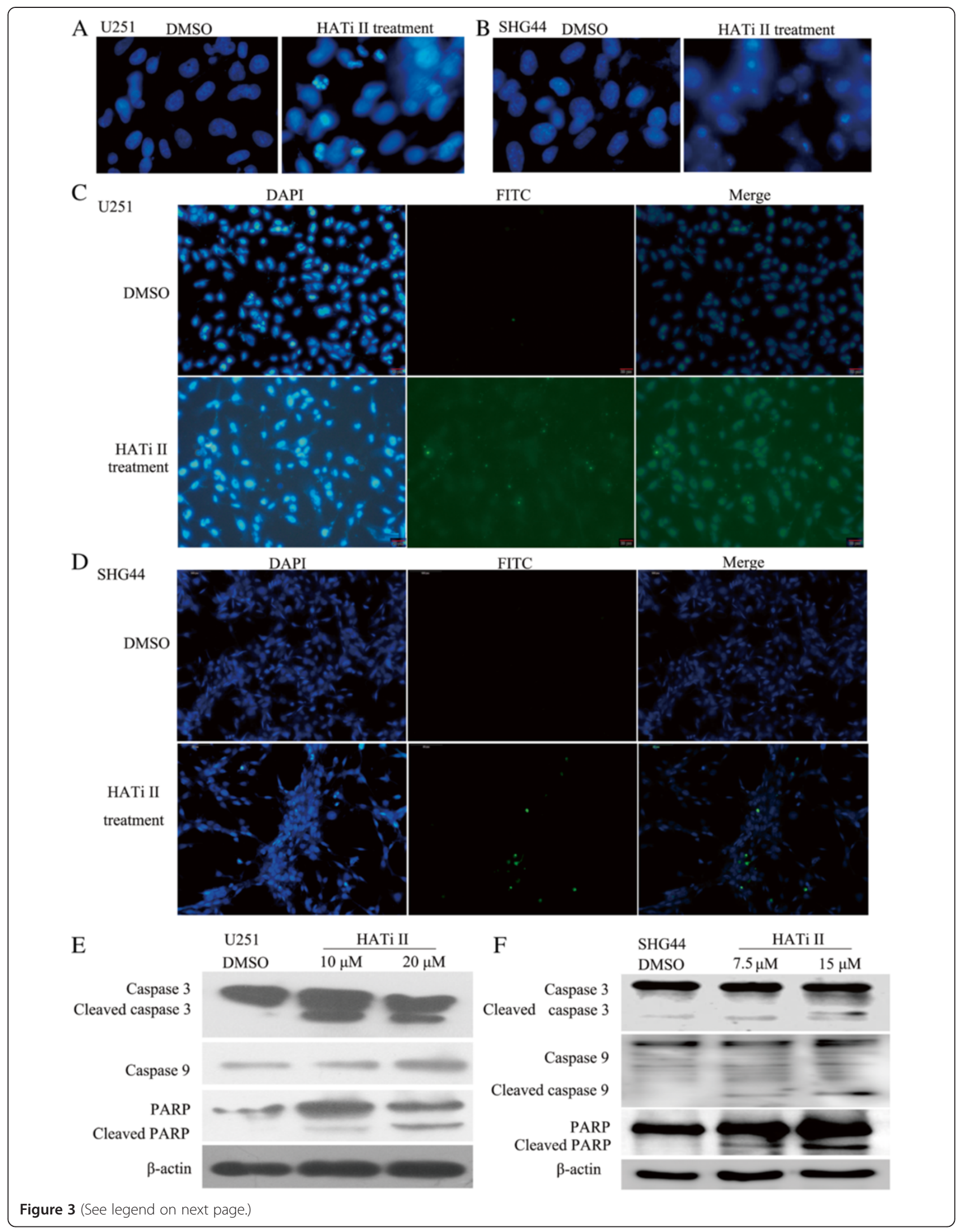


(See figure on previous page.)

Figure 3 HATi II induces apoptosis, DNA fragmentation and activation of caspase-3 in glioma cell lines. (A, B) The morphologic changes in U251 (A) and SHG44 cells (B) treated with HATi II were evaluated using Hoechst 33342 staining and fluorescence microscopy. (C, D) Apoptosis was assessed by terminal deoxynucleotidyl transferase mediated dUTP nick end-labeling (TUNEL) analysis in U251 (C) and SHG44 cells (D) treated with HATi II. Apoptotic cells (green) were detected by laser scanning confocal microscopy at an excitation of 515-565 nm, while the cell nuclei were stained with DAPI. The two images have been superimposed to show the apoptotic cells (green) and their position. (E and F) Western-blot analysis of the activation of caspase-3, caspase-9 and PARP in U251 (E) and SHG44 cells (F) treated with HATi II for 48 h.

fold change filtering between the two samples using a threshold fold change of $\geq 2.0$. Further data analysis was performed using Agilent GeneSpring GX v12.0 software; this analysis was performed by KangChen Biotech, Shanghai, PR China.

\section{Gene ontology analysis and pathway analysis}

Gene ontology (GO) analysis is a functional analysis that associates differentially expressed mRNAs with GO categories. The GO categories were derived from Gene Ontology (www.geneontology.org), which comprises three structured networks of defined terms that describe gene product attributes. The ontology covers three domains: biological process, cellular component and molecular function. Fisher's exact test was used to determine whether the overlap between the differentially expressed (DE) list and the GO annotation list was greater than that expected by chance. The $P$-value denotes the significance of the GO term enrichment in the DE genes after accounting for the false discovery rate. The lower the $P$-value, the more significant the GO term (a $P$-value $\leq 0.05$ is recommended).

Pathway analysis is a functional analysis that maps genes to KEGG (Kyoto Encyclopedia of Genes and Genomes) pathways (http://www.genome.jp/kegg/). The $P$-value (EASE-score, Fisher's exact test $P$ value, or hypergeometric $P$-value) denotes the significance of the pathway correlated to the conditions. The lower the $P$-value, the more significant the correlation (the recommended $P$-value cut-off is 0.05 ).

\section{Real-time PCR verification of differentially expressed target genes}

Total cellular RNA was isolated using TRIzol reagent (Invitrogen, CA, USA ) according to the manufacturer's protocol and $1 \mu \mathrm{g}$ of total RNA was reverse transcribed to cDNA using the ReverTra Ace qPCR RT Kit (Toyobo, Osaka, Japan) following the manufacturer's instructions. Real-time PCR array analysis was performed in a total volume of $20 \mu \mathrm{l}$, including $2 \mu \mathrm{l}$ of cDNA, primers $(0.2 \mathrm{mM}$ each) and $10 \mu \mathrm{l}$ of SYBR Green mix (Roche). Reactions were run on an Light cycler 480 (Roche) using universal thermal cycling parameters $\left(95^{\circ} \mathrm{C}\right.$ for $5 \mathrm{~min}$, 45 cycles of $10 \mathrm{sec}$ at $95^{\circ} \mathrm{C}, 20 \mathrm{sec}$ at $60^{\circ} \mathrm{C}$ and $15 \mathrm{sec}$ at $72^{\circ} \mathrm{C}$; melting curve: $10 \mathrm{sec}$ at $95^{\circ} \mathrm{C}, 60 \mathrm{sec}$ at $60^{\circ} \mathrm{C}$ and then continued melting). Results were obtained using the sequence detection software of the Light cycler 480 and analyzed using Microsoft Excel. The sequences of the primers for the seven target genes and the internal control gene $(G A P D H)$ are listed in Additional file 1: Table S1.

\section{Statistical analysis}

The mean $\pm \mathrm{SD}$ values presented in the figures were calculated from three or more independent experiments. Comparisons between groups were evaluated using twotailed Student's $t$-tests; $p<0.05$ was considered statistically significant.

\section{Results}

HATi II inhibits the proliferation of glioma cells

U251, U87, SHG44 and HS683 cells were treated with different concentrations of HATi II $(0,2.5,5,7.5,10$, $12.5,15,20$ or $25 \mu \mathrm{mol} / \mathrm{L})$ for $48 \mathrm{~h}$, then cell proliferation was assessed using the CCK- 8 kit. HATi II inhibited proliferation in a dose-dependent manner in all four glioma cell lines; DMSO $(\leq 0.1 \%)$ had negligible influence on cell proliferation. The $\mathrm{IC}_{50}$ values for $\mathrm{HATi}$ II at $48 \mathrm{~h}$ in U251, U87 and HS683 cells were approximately $12.17 \pm 0.7489 \mu \mathrm{mol} / \mathrm{L}, 9.513 \pm 0.8632 \mu \mathrm{mol} / \mathrm{L}$ and $9.558 \pm 1.081 \mu \mathrm{mol} / \mathrm{L}$; SHG44 cells were more sensitive to HATi II than the other three cell lines with an $\mathrm{IC}_{50}$ of $5.9688 \pm 0.5351 \mu \mathrm{mol} / \mathrm{L}$ (Figure 1A-1D).

Under the phase-contrast microscope, we observed that treatment with HATi II markedly decreased the numbers of U251, HS683, U87 and SHG44 cells, and a large proportion of the remaining cells became rounded and smaller in size indicating that the cells were undergoing apoptosis (Figure 1E).

\section{HATi II induces apoptosis in U251 and SHG44 cells}

To confirm whether HATi II induces apoptosis in glioma cells, we subjected HATi II-treated U251 cells to the Annexin V assay. Flow cytometry demonstrated that treatment with 10 or $20 \mu \mathrm{M}$ HATi II for 24 or 48 h significantly increased the numbers of apoptotic cells compared to control cells. The percentage of apoptotic cells in the HATi II $10 \mu \mathrm{M}$ group was $11 \% \pm 2.2 \%$ at $24 \mathrm{~h}$ and $22.8 \% \pm 1.7 \%$ at $48 \mathrm{~h}$, the percentage of apoptotic cells in the HATi II $20 \mu \mathrm{M}$ group was $18.7 \% \pm 0.8 \%$ at $24 \mathrm{~h}$ and $34.9 \% \pm 3.3 \%$ at $48 \mathrm{~h}$, compared to $3.6 \% \pm$ $1.02 \%$ at $24 \mathrm{~h}$ and $5.7 \% \pm 0.56 \%$ at $48 \mathrm{~h}$ for control cells $(P<0.01$; Figure $2 \mathrm{~A}$ and $2 \mathrm{~B})$. Cell cycle alterations were 


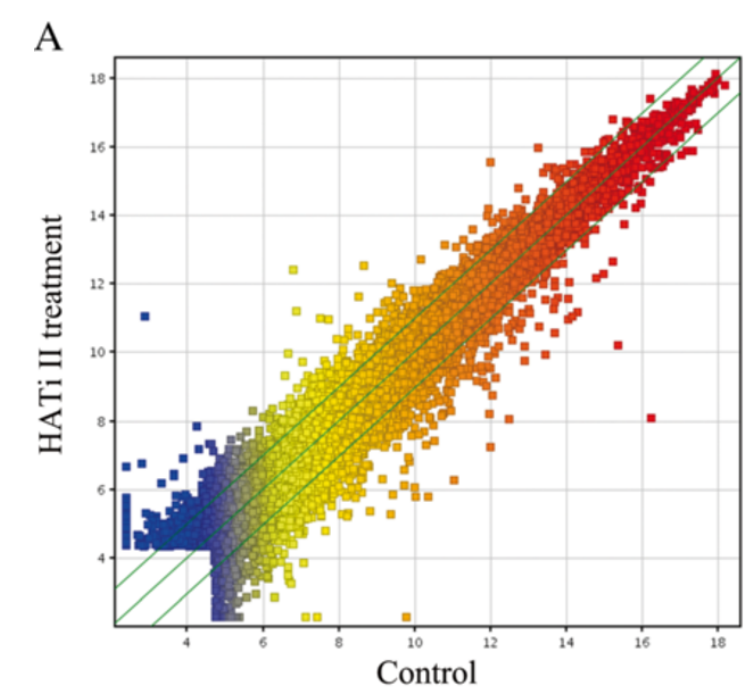

B

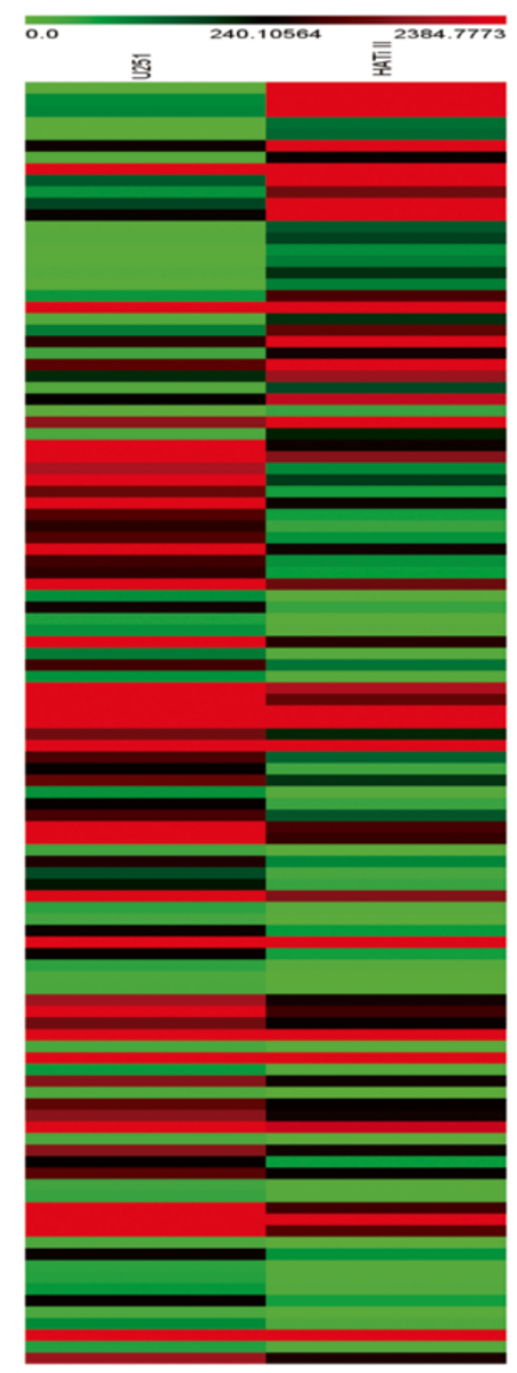

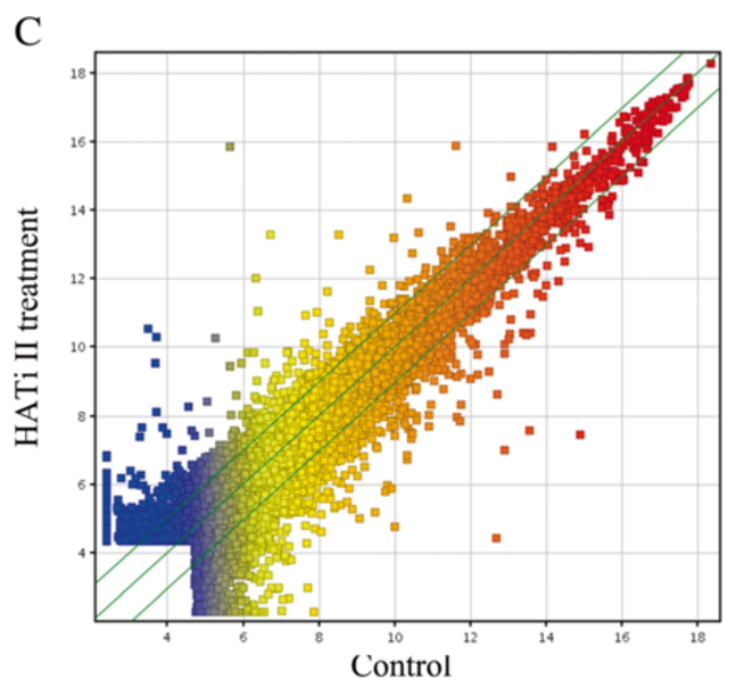

D

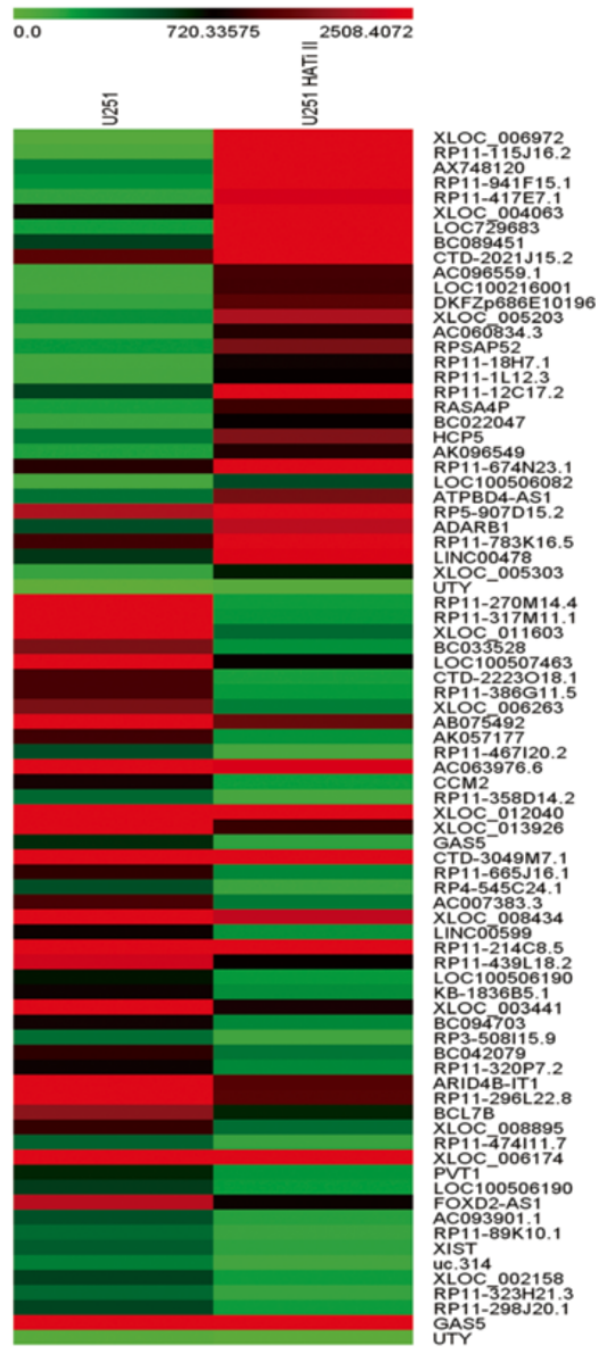

Figure 4 (See legend on next page.)

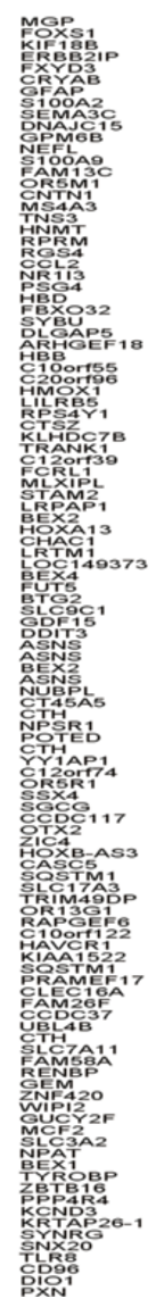


(See figure on previous page.)

Figure 4 Microarray analysis of the expression profiles of HATi II-treated and DMSO-treated U251 cells. (A, B) The box plot is a convenient way to quickly visualize the distributions of a dataset for mRNA (A) and IncRNA (B) profiles. The distributions of the log 2 ratios between the groups after normalization are presented. (C) Differentially expressed mRNAs and (D) differentially expressed IncRNAs were analyzed using hierarchical clustering. Hierarchical clustering analysis arranges samples into groups based on their expression level, which allows us to evaluate the relationships between samples. "Red" indicates high relative expression, and "green" indicates low relative expression (mRNA fold changes $\geq 5$ and IncRNA fold changes $\geq 3$ ).

confirmed using the cell cycle assay (Figure 2C). As expected, DNA fragmentation was observed and increased in a time dependent manner. The number of apoptotic cells in the HATi II $10 \mu \mathrm{M}$ group was $11.89 \% \pm 1.7 \%$ at $24 \mathrm{~h}$ and $22.64 \% \pm 4.4 \%$ at 48 hours; similar results were obtained for SHG44 cells treated with 7.5 or $15 \mu \mathrm{M}$ HATi II for 24 or $48 \mathrm{~h}$ (Figure 2D-F).

As shown in Figure 3A and 3B, apoptotic bodies were clearly observed in U251 and SHG44 cells that had been treated with HATi II for $48 \mathrm{~h}$ and then stained with Hochest 33342. Additionally, the TUNEL assay showed that HATi II markedly increased the number of apoptotic cells relative to the respective control U251 and SHG44 cells treated with DMSO (Figure 3C and 3D). These results were consistent with the Annexin $\mathrm{V}$ assay and cell cycle analysis, and confirmed that HATi II induces apoptosis in U251 and SHG44 cells. We obtained similar results in U87 and HS683 treated with HATi II (Additional file 2: Figure S1).

HATi II induces caspase-dependent apoptosis in glioma cells As we observed that HATi II induced apoptosis in glioma cells, we examined the cleavage of PARP, caspase- 9 and caspase- 3 by Western blotting. The expression of cleaved caspase-3, caspase-9 and PARP increased markedly in U251 cells treated with 10 or $20 \mu \mathrm{M}$ HATi II for $48 \mathrm{~h}$ and SHG44 cells treated with 7.5 or $15 \mu \mathrm{M}$ HATi II for $48 \mathrm{~h}$ (Figure 3E and 3F). Additionally, caspase-3 and PARP underwent cleavage in a dose-dependent manner in U251 and SHG44 cells treated with HATi II. These results confirmed that HATi II induces apoptosis in glioma cells by activating the caspase-dependent pathway. We obtained similar results in U87 and HS683 cells treated with HATi II (Additional file 3: Figure S2).

\section{Microarray analysis of differentially expressed genes in HATi II-treated U251 cells}

The Arraystar_Human_LncRNA_8x60k v3.0 1 microarray was used to identify differentially expressed lncRNA/ mRNA in HATi II-treated U251 cells for $48 \mathrm{~h}$ compared to DMSO-treated control cells. The threshold of volcano plot filtering used to screen the differentially expressed mRNAs was a fold change $>2.0$. In the lncRNA/mRNA expression profiling data, we identified a total of 23773 mRNAs and 1949 differently expressed mRNAs in HATi II-treated
U251 cells (Figure 4A, Additional file 4: Table S2 and Additional file 5: Table S3). Compared to DMSO-treated control cells, 965 mRNAs were significantly upregulated and 984 mRNAs were significantly downregulated in HATi II-treated U251 cells. Clustering analysis was used to visualize the relationships between the mRNA expression patterns present in the samples (fold changes $\geq 5$; Figure 4B).

In the lncRNA expression profiling data, we found a total of 33327 long non-coding RNAs (lncRNAs) expressed in U251 cells, of which 3492 were differently expressed in HATi II-treated cells (Figure 4C, Additional file 6: Table S4 and Additional file 7: Table S5). Hierarchical clustering analysis of the differently expressed lncRNAs with a fold change $\geq 3$-fold is presented in Figure 4D. A total of 743 lncRNAs close to coding genes were identified to be changed after HATi II treatment (Additional file 8: Table S6).

\section{Gene ontology analysis of differentially expressed mRNA s}

We performed ontologic pathway enrichment analysis for the differently expressed genes and gene product enrichment with particular attention to GO biological processes and molecular function. Fisher's exact test was used to determine whether the overlap between the differentially expressed gene list and the GO annotation list was greater than that expected by chance (a $P$-value $\leq 0.05$ is recommended).

We found that the most enriched GOs targeted by the upregulated and downregulated transcripts were involved in a variety of functions including cellular processes, biological regulation, cell cycle, response to stimulus, immune and defense response, signal transduction, transcriptional regulation and metabolism (Figure 5A and 5B). The genes associated with the most enriched GO terms in HATi IItreated U251 cells were linked to DNA ligation, regulation of protein processing, cell cycle and mitosis, and oxygen transporter activity, and included HBMG2, CRCC4, TOP2A, RAD51, A2M, C3, F12, KLKB1, GTSE1, CETN2, PLK4, $K L F 11, K L F 3 B$ and $H B M$ (Additional file 9: Table S7). In contrast, the genes associated with the most enriched GO terms in DMSO-treated U251 control cells included factors involved in response to stimulus, immune system and defense processes, and included S100A7, MMP3, BCL2, HMOX1, APCS, IGF1, SP3, FOS, CXCL1, TIMP3, DUSP6, $M A P K 10, C L E C 7 A$ and TLR8 (Additional file 10: Table S8). 
A

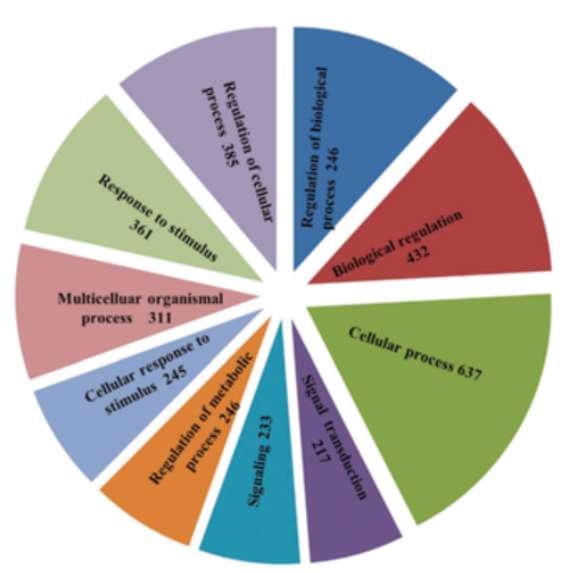

C

Top 5 up-regulated pathways

1 Alcoholism

2 p53 signaling pathway

3 Focal adhesion

4 Propanoate metabolism

$5 \quad$ Systemic lupus erythematosus

D

Top 5 down-regulated pathways

1 Cytokine-cytokine receptor interaction

2 Transcriptional misregulation in cancer

3 Jak-STAT signaling pathway

4 Glycosphingolipid biosynthesis

5 Selenocompound metabolism
B

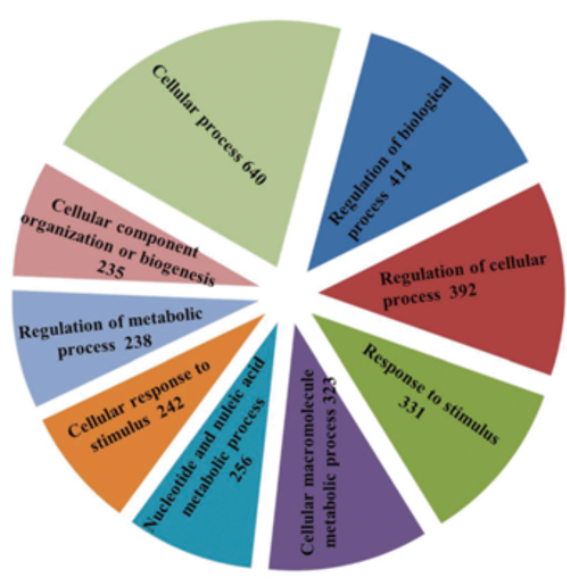

Enrichment Score Genes

$3.76973 \mathrm{E} \quad 21$

$3.371258 \mathrm{E} \quad 11$

$2.971844 \mathrm{E} \quad 21$

$2.38265 \mathrm{E} \quad 6$

$2.141798 \mathrm{E} \quad 14$

Enrichment Score Genes

$3.123155 \mathrm{E} \quad 27$

$3.015776 \mathrm{E} \quad 20$

$2.922727 \mathrm{E} \quad 18$

2.211829E $\quad 4$

2.006005E $\quad 4$

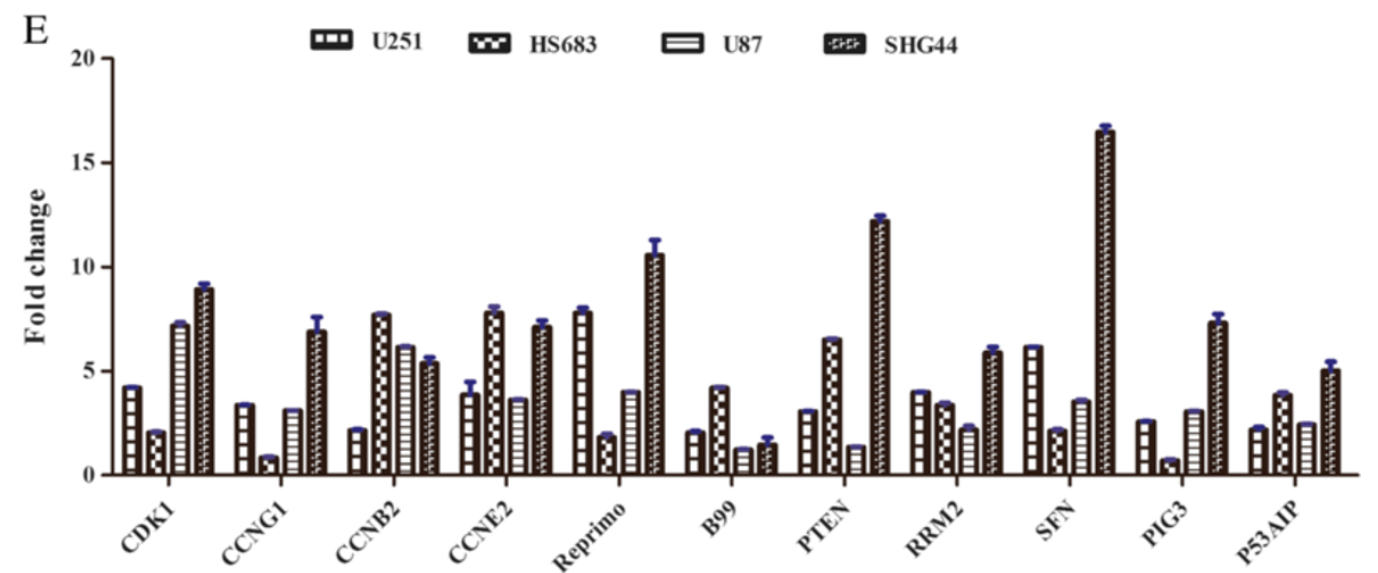

Figure $\mathbf{5}$ (See legend on next page.) 
(See figure on previous page.)

Figure $\mathbf{5}$ Bioinformatic analysis of the differentially expressed genes in HATi II-treated U251 cells. Gene ontology enrichment analysis provides a controlled vocabulary to describe the attributes of differentially expressed transcripts in all organisms ( $p$-values $\leq 0.05$ are

recommended). (A) Upregulated genes and (B) downregulated genes in HATi II-treated U251 cells. Pathway analysis is a functional analysis that maps genes to KEGG pathways. The top five upregulated pathways (C) and top five downregulated pathways (D) in HATi II-treated U251 cells are listed. The "p53 signaling pathway", which is associated with apoptosis, was activated in HATi II-treated U251 cells. (E) Confirmation of the microarray results. The expression of p53 signaling pathway-related genes in HATi II-treated U251, HS683, U87 and SHG44 cells was validated by quantitative real-time PCR. The columns represent the log-transformed median fold changes in expression relative to DMSO-treated cells.

\section{Pathway analysis and certification}

The KEGG database was used to investigate the pathways in which the differentially expressed genes are involved. KEGG pathway annotations of the five most enriched pathways are shown in Figure 5C and 5D. Specifically, the upregulated pathways included alcoholism, p53 signaling pathway, focal adhesion, propanoate metabolism, cell cycling, regulation of actin cytoskeleton and ECM-receptor interactions. One of these pathways, the p53 signaling pathway, contained 11 genes that were upregulated in HATi II-treated cells.

To validate the results of the mRNA microarray assay, quantitative RT-PCR analysis was performed to confirm the expression of genes related to the p53 signaling pathway in HATi II-treated U251, HS683, U87 and SHG44 cells and DMSO-treated control cells. Quantitative RTPCR demonstrated that CDK1, CCNG1, CCNE2, CCNB2, Reprimo (RPRM), GTSE1 (B99), PTEN, SFN (stratifin), RRM2, TP53I3 (PIG3) and P53AIP were upregulated by HATi II (Figure 5E); these results were mostly consistent with the results of microarray analysis.

Significant changes in the protein levels of factors related to the p53 pathway were also observed in U251 cells treated with HATi II, as shown in Figure 6A and 6B. P53 and p21 were obviously upregulated by HATi II treatment in a dose-dependent manner. A number of proteins downstream of the p53 signaling pathway, such as CDK1, CCNE2, Reprimo, PTEN, SFN and RRM2, were also significantly increased in a dose-dependent manner in U251 cells treated with HATi II, compared to control cells (Figure 6B and 6C). These results indicate that HATi II may activate $\mathrm{p} 53$ and promote transcription and activation of genes downstream of the p53 pathway. As shown in Figure $6 \mathrm{~A}$ and $6 \mathrm{~B}$, Reprimo was significantly upregulated by HATi II at both the mRNA and protein level. To determine the function of Reprimo in glioma cells treated with HATi II, we knocked down the expression of Reprimo in U251 cells using a siRNA. Silencing of reprimo attenuated HATi II-induced cell death, (Figure 6E) and reduced the number of apoptotic cells by almost 25\% (Figure 6F).

\section{Discussion}

At present, the therapeutic options for glioma are insufficient, and more effective therapeutic options are urgently required; small-molecule inhibitors may represent specific, less toxic candidate drugs. Recent research has indicated that a variety of small-molecule inhibitors that target HATs can induce growth arrest, inhibit proliferation, induce apoptosis or affect differentiation in tumor cells [16-18]. HATi II, a novel p300/CBP-selective HAT inhibitor reduced histone $\mathrm{H} 3$ acetylation and induced chromatin condensation in HeLa cells. In this study, we investigated the effects and mechanism of action of HATi II in glioma cell lines.

In this study, we demonstrated that HATi II can inhibit the growth of glioma cell lines, as well as neuroblastoma and Wilms tumor cell lines (data not shown), which suggests that HATi II exerts broad spectrum anti-cancer activity. P300 is required for orderly G1/S cell cycle phase transition in human cancer cells, and inhibition of p300 blocks progression into the S-phase of cell cycle $[26,28]$. The p300/CBP HAT inhibitor compound C646 has been shown to inhibit the growth of both melanoma and nonsmall-cell-lung (NSCL) cancer cell lines [22]. In our study, the CKK-8 assay, Hoechst 33342 staining, the Annexin V assay, flow cytometry and the TUNEL assay demonstrated that HATi II inhibited proliferation and induced cell cycle arrest and apoptosis in glioma cell lines. DNA fragmentation was observed after $24 \mathrm{~h}$ in HATi II-treated cells, and increased in a time-dependent manner. In prostate cancer cells, inhibition of p300 induced apoptosis via multiple pathways, and also decreased the expression of MMP-2 and MMP-9, which reduced the migratory and invasive ability of the cells [25].

Apoptosis is a genetically controlled mechanism of cell death that is essential for the elimination of unwanted cells during normal development and for the maintenance of tissue homeostasis [29,30]. Classical caspase-dependent apoptosis requires proteolytic activation of caspases that are synthesized as latent proenzymes. Once activated, caspases cleave a wide range of molecules, eventually resulting in cellular destruction [31]. Cleavage of PARP by caspases is considered to be a hallmark of apoptosis. In our experiments, HATi II increased the expression of cleaved PARP, caspase-9 and caspase-3 in U251 and SHG44 cells. Cleavage of caspase- 3 and PARP is indicative of apoptosis and confirmed that HATi II induced apoptosis via the caspase-dependent pathway. This observation 


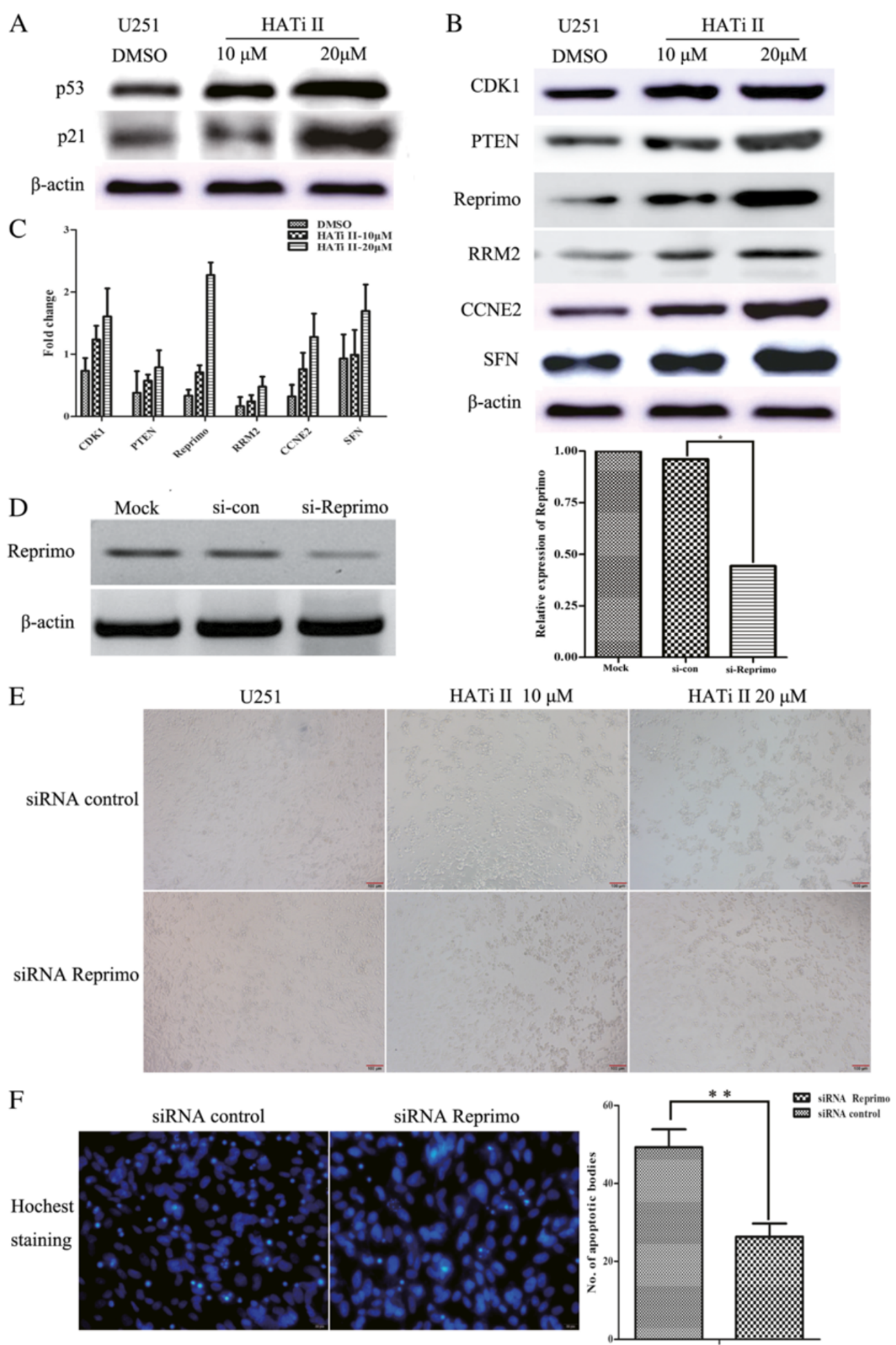

Figure 6 (See legend on next page.) 
(See figure on previous page.)

Figure 6 Protein expression of factors related to the p53 signaling pathway in U251 cells treated with HATi II. Western blot analysis of p53 and p21 (A) and factors downstream of the p53 signaling pathway (B, C) in U251 cells treated with HATi II. (D) Western blot analysis confirming siRNA-mediated knockdown of Reprimo. (E) The morphological assay indicated that knockdown of Reprimo markedly reduced cell death in a dose-dependent manner in U251 cells treated with 10 or 20 umol/I HATi II for 48 h. (F) The hoechst 33342 staining assay indicated that knockdown of Reprimo reduced apoptosis in U259 cells treated with 10 Hmol/I HATi II for 48 h compared with control cells; ${ }^{* *} P<0.01$.

is in keeping with recent reports of the proapoptotic activity of NU9056, which is a histone acetyltransferase inhibitor. NU9056 inhibits cell growth and induces apoptosis via caspase activation in prostate cancer cell lines [32]. In addition, it is noteworthy that both cell cycle arrest and apoptosis were observed in neuroblastoma cell lines (IMR-32 and SH-SY5Y) treated with HATi II (data not shown), which suggests that HATi II has potential for use in the clinic.

Microarray analysis demonstrated that 965 mRNAs were significantly upregulated and 984 mRNAs were significantly downregulated ( $\geq 2.0$-fold) in HATi II-treated U251 cells. Additionally, 3492 lncRNAs were identified to be differently expressed in HATi II-treated U251 cells. In recent years, multiple studies have demonstrated that nearly every step in the life cycle of a gene can be regulated by lncRNAs [33]. Nevertheless, the role of lncRNAs in apoptosis not well-studied. In this study, a total of 743 lncRNAs close to coding genes were identified to changed in HATi II-treated cells. Serine/threonine kinase 40 (STK40), a negative regulator of NF-kappa-B and p53mediated gene transcription [34], is the coding gene closest to lncRNA chr1:36804800-36856000+, which was upregulated 10-fold after HATi II treatment. BCL2associated athanogene 6 (BAG6), the coding gene closest to IncRNA NR_002812 that was upregulated 5-fold by HATi II, is implicated in the regulation of apoptosis. After DNA damage, BAG6 accumulates in the nucleus and forms a complex with p300/EP300, enhancing p300/ EP300-mediated p53/TP53 acetylation leading to increased p53/TP53 transcriptional activity $[35,36]$. In addition, RASSF1 (Ras Association (RalGDS/AF-6) Domain Family Member 1) is the coding gene closest to the downregulated lncRNA BC033528, RASSF1 has been shown to induce cell cycle arrest and is required for death receptordependent apoptosis [37]. Therefore, these results indicate that lncRNAs may play a role in HATi II-induced apoptosis in glioma cell lines.

GO analysis showed that the differentially expressed mRNAs with known functions are involved in a variety of processes including cellular processes, biological regulation, cell cycle, response to stimulus, immune and defense response, signal transduction, transcriptional regulation and metabolism. Numerous signaling pathways and molecules are involved in apoptosis $[29,38]$. One major apoptotic signaling pathway involves the p53 tumor suppressor.
KEGG pathway annotation demonstrated that the p53 signaling pathway was activated by HATi II, which suggested that HATi II may induce apoptosis in U251 cells via activation of the p53 signaling pathway. Based on our analysis of this analysis, quantitative realtime PCR was used to verify the expression of a number of crucial target genes downstream of p53, to test the hypothesis that HATi II induces p53 transcriptiondependent death and exclude the possibility of false positive results from the microarray.

A number of differently expressed genes were chosen as markers of the transcriptional function of p53. CDK1, CCNG1, CCNE2, CCNB2 and $p 53$ are transcriptionally regulated at different phases of the cell cycle. Reprimo appears to induce cell cycle arrest by inhibiting CDK1 activity and nuclear translocation of the CDC2 cyclin B1 complex, and may be involved in regulation of $\mathrm{p} 53$ dependent G2 cell cycle arrest. B99 is only expressed in the $S$ and $G 2$ phases of the cell cycle, and in response to DNA damage, it accumulates in the nucleus and binds to p53, which shuttles it out of the nucleus and represses its ability to induce apoptosis [39]. Tumor protein p53-inducible protein 3 (TP53I3) is induced by the tumor suppressor p53 and is thought to be involved in p53-mediated cell death [40]. Quantitative real-time PCR demonstrated that these p53-transcriptionally regulated molecules, including CDK1, CCNG1, CCNE2, CCNB2, Reprimo, GTSE1, PTEN, SFN, TP53I3 and DDB2 were upregulated by HATi II in U251 cells, in confirmation of the results of the microarray. Significant dosedependent increases in the protein levels of p53 and p21 were also observed subsequent to treatment with HATi II. Other proteins downstream of the p53 signaling pathway, such as CDK1, CCNE2, Reprimo, PTEN, SFN and RRM2, were also significantly and dose-dependently upregulated by HATi II.

The p53 pathway has been reported to be involved in a large number of biological processes, including acetylation. P53 was the first non-histone protein shown to be acetylated by HATs, and p53 acetylation is mediated by the p300 and CBP acetyltransferases in vivo [41]. Thus, we suggest that inhibition of HATs may lead to deacetylation of p53 and result in transactivation of the p53-regulated genes that regulate apoptosis. However, additional research is required to explore the precise mechanism by which HATi II affects the p53 pathway. 


\section{Conclusions}

HATi II inhibits proliferation and induces apoptosis via the caspase-dependent pathway in glioma cell lines, possibly by activating the p53 signaling pathway. This study provides a basis for further investigation of the molecular mechanism by which HATi II induces apoptosis and indicates that HATi II may have potential as a therapeutic option for human glioma.

\section{Additional files}

Additional file 1: Table S1. Primers used in this study.

Additional file 2: Figure S1. HATi II induces apoptosis in glioma cell lines. (A-C) U87 cells or (D-F) HS683 cells were treated with HATi II for 24 or $48 \mathrm{~h}$ and apoptosis was determined by Annexin V-FITC/PI dual labeling and flow cytometry (A, D), and the numbers of Annexin $\mathrm{V}(+)$ and $\mathrm{PI}(-) \%$ cells were quantified $(\mathbf{B}, \mathbf{E}) ;{ }^{*} P<0.05$ or ${ }^{* *} P<0.01$ compared with DMSOtreated control cells. (C, F) Cell cycle analysis of U87 and HS683 cells treated with HATi II for 24 or 48 h; DNA fragmentation was observed after $24 \mathrm{~h}$ and increased in a time-dependent manner. These analyses were repeated three times.

Additional file 3: Figure S2. HATi II induces apoptosis, DNA fragmentation and activation of caspase-3 in glioma cell lines. (A, B) The morphologic changes in U87 (A) and HS683 cells (B) treated with HATi II were evaluated using Hoechst 33342 staining and fluorescence microscopy. (C, D) Apoptosis was assessed by terminal deoxynucleotidyl transferase mediated dUTP nick end-labeling (TUNEL) analysis in U87 (C) and HS683 cells (D) treated with HATi II. Apoptotic cells (green) were detected by laser scanning confocal microscopy at an excitation of 515-565 nm, while the cell nuclei were stained with DAPI. The two images have been superimposed to show the apoptotic cells (green) and their position. (E and F) Western blot analysis of the activation of caspase-3, caspase-9 and PARP in U87 (E) and HS683 cells (F) treated with HATi II for $48 \mathrm{~h}$.

Additional file 4: Table S2. Expression profiles of differentially expressed mRNAs in HATi II-treated and DMSO-treated U251 cells. Sheet 1 represents all target values; Sheet 2 is a boxplot view used to compare the distributions of the expression values for the samples in an experiment after normalization; Sheet 3 is a scatterplot, a useful method for assessing the variation between chips; Sheet 4 is the hierarchical clustering, showing distinguishable mRNA expression changes between the samples.

Additional file 5: Table S3. Differentially expressed mRNAs in HATi IItreated U251 cells. Sheet 1 represents mRNAs upregulated in HATi Il-treated U251 cells and Sheet 2 represents mRNAs downregulated in HATi II-treated U251 cells, compared to DMSO-treated control cells.

Additional file 6: Table S4. Expression profiles of differentially expressed IncRNAs in HATi II-treated and DMSO-treated U251 cells. Sheet 1 represents all target values; Sheet 2 is a boxplot view used to compare the distributions of the expression values for the samples in an experiment after normalization; Sheet 3 is a scatterplot, a useful method for assessing the variation between chips; Sheet 4 is the hierarchical clustering, showing distinguishable mRNA expression changes between the samples.

Additional file 7: Table S5. Differentially expressed IncRNAs in HATi II-treated U251 cells. Sheet 1 represents IncRNAs upregulated in HATi II-treated U251 cells and Sheet 2 represents IncRNAs downregulated in HATi II-treated U251 cells, compared to DMSO-treated control cells.

Additional file 8: Table S6. LncRNAs nearby coding genes.

Additional file 9: Table S7. GO analysis of the molecular function of the upregulated mRNAs in HATi II-treated U251 cells.

Additional file 10: Table S8. GO analysis of the biological processes related to the upregulated mRNAs in HATi II-treated U251 cells.

\section{Abbreviations}

CBP: CREB-binding protein; PARP: Poly ADP-ribose polymerase; HATs: Histone acetyltransferases; HDACs: Histone deacetylases; HATi II: Histone acetyltransferase inhibitor II; PCAF: P300/CBP-associated factor; DAPI: 4',6-diamidino-2-phenylindole; p53: tumor suppressor p53; AML: Acute myelocytic leukemia; TUNEL: TdT-mediated dUTP Nick-End Labeling; NSCL: Melanoma and non-small-cell-lung; STK40: Serine/threonine kinase 40; BAG6: BCL2-associated athanogene 6; MMP 2: Matrix metalloprotein 2; MMP 9: Matrix metalloprotein 9; RASSF1: Ras Association (RalGDS/AF-6) Domain Family Member 1.

\section{Competing interests}

The authors declare that they have no competing interests.

\section{Authors' contributions}

XF and JP designed and directed the study. LXX and ZHL participated in protocol development and performed most of the experiments and drafted this manuscript. YFT designed the primer of PCR, finished the experiments of Real-time PCR, collected samples for microarray. $\mathrm{RHL}$ participated in the cell culture and western blotting assay. FF participated in data analysis. $\mathrm{HZ}, \mathrm{GL}$, YHL and JW participated in study design and coordination, data analysis and interpretation and drafted the manuscript. All authors read and approved the final manuscript.

\section{Acknowledgements}

This work was supported by grants from the Key Medical Project of Jiangsu Province, China (XK201120), the Natural Science Foundation of Jiangsu Province, China (BK2011311), the Special Clinical Medical Science and Technology of Jiangsu Province, China (BL2012050), the Key Laboratory of Suzhoun China (SZS201108, SZS201307), the Science and Technology Project of Suzhou, China (SYSD2013105, SYS201446), and the National Natural Science Foundation of China $(81271378,81471488,81100371,81300423)$.

\section{Author details}

${ }^{1}$ Institute of Pediatric Research, Children's Hospital affiliated to Soochow University, Suzhou 215006, China. ${ }^{2}$ Department of Hematology and Oncology, Children's Hospital of Soochow University, Suzhou 215006, China ${ }^{3}$ Department of Neonatology, Children's Hospital of Soochow University, Suzhou 215006, China.

Received: 8 August 2014 Accepted: 1 December 2014

Published online: 19 December 2014

\section{References}

1. Alebouyeh M, Moussavi F: Occurrence of overwhelming gram-negative infections in splenectomised patients with thalassaemia major. Eur J Pediatr 2003, 162(9):637-638.

2. Echevarria ME, Fangusaro J, Goldman S: Pediatric central nervous system germ cell tumors: a review. Oncologist 2008, 13(6):690-699.

3. Qaddoumi I, Sultan I, Gajjar A: Outcome and prognostic features in pediatric gliomas: a review of 6212 cases from the Surveillance, Epidemiology, and End Results database. Cancer 2009, 115(24):5761-5770.

4. Louis DN, Ohgaki H, Wiestler OD, Cavenee WK, Burger PC, Jouvet A, Scheithauer BW, Kleihues P: The 2007 WHO classification of tumours of the central nervous system. Acta Neuropathol 2007, 114(2):97-109.

5. Nomura M, Narita Y, Miyakita Y, Ohno M, Fukushima S, Maruyama T, Muragaki Y, Shibui S: Clinical presentation of anaplastic large-cell lymphoma in the central nervous system. Molecular and clinical oncology 2013, 1(4):655-660.

6. Wen PY, Kesari S: Malignant gliomas in adults. N Engl J Med 2008 359(5):492-507.

7. Stupp R, Mason WP, van den Bent MJ, Weller M, Fisher B, Taphoorn MJ, Belanger K, Brandes AA, Marosi C, Bogdahn U, Curschmann J, Janzer RC, Ludwin SK, Gorlia T, Allgeier A, Lacombe D, Cairncross JG, Eisenhauer E, Mirimanoff RO: Radiotherapy plus concomitant and adjuvant temozolomide for glioblastoma. N Engl J Med 2005, 352(10):987-996.

8. Sathornsumetee $\mathrm{S}$, Rich JN: New treatment strategies for malignant gliomas. Expert Rev Anticancer Ther 2006, 6(7):1087-1104.

9. Minniti G, Muni R, Lanzetta G, Marchetti P, Enrici RM: Chemotherapy for glioblastoma: current treatment and future perspectives for cytotoxic and targeted agents. Anticancer Res 2009, 29(12):5171-5184.

10. Strahl BD, Allis CD: The language of covalent histone modifications. Nature 2000, 403(6765):41-45 
11. Shahbazian MD, Grunstein M: Functions of site-specific histone acetylation and deacetylation. Annu Rev Biochem 2007, 76:75-100.

12. Hagelkruys A, Sawicka A, Rennmayr M, Seiser C: The biology of HDAC in cancer: the nuclear and epigenetic components. Handb Exp Pharmacol 2011, 206:13-37.

13. Ropero S, Esteller M: The role of histone deacetylases (HDACs) in human cancer. Mol Oncol 2007, 1(1):19-25.

14. Roth SY, Denu JM, Allis CD: Histone acetyltransferases. Annu Rev Biochem 2001, 70:81-120

15. Yang XJ: The diverse superfamily of lysine acetyltransferases and their roles in leukemia and other diseases. Nucleic Acids Res 2004, 32(3):959-976.

16. Marks PA, Richon VM, Rifkind RA: Histone deacetylase inhibitors: inducers of differentiation or apoptosis of transformed cells. J Natl Cancer Inst 2000, 92(15):1210-1216.

17. Marks PA, Xu WS: Histone deacetylase inhibitors: Potential in cancer therapy. J Cell Biochem 2009, 107(4):600-608.

18. Witt O, Deubzer HE, Lodrini M, Milde T, Oehme I: Targeting histone deacetylases in neuroblastoma. Curr Pharm Des 2009, 15(4):436-447.

19. Eliseeva ED, Valkov V, Jung $M$, Jung MO: Characterization of novel inhibitors of histone acetyltransferases. Mol Cancer Ther 2007, 6(9):2391-2398.

20. Balasubramanyam K, Swaminathan V, Ranganathan A, Kundu TK: Small molecule modulators of histone acetyltransferase p300. J Biol Chem 2003, 278(21):19134-19140.

21. Lenoci A, Tomassi S, Conte M, Benedetti R, Rodriguez V, Carradori S, Secci D, Castellano S, Sbardella G, Filetici P, Novellino E, Altucci L, Rotili D, Mai A: Quinoline-based p300 histone acetyltransferase inhibitors with pro-apoptotic activity in human leukemia U937 cells. ChemMedChem 2014, 9(3):542-548

22. Bowers EM, Yan G, Mukherjee C, Orry A, Wang L, Holbert MA, Crump NT, Hazzalin CA, Liszczak G, Yuan H, Larocca C, Saldanha SA, Abagyan R, Sun Y, Meyers DJ, Marmorstein R, Mahadevan LC, Alani RM, Cole PA: Virtual ligand screening of the p300/CBP histone acetyltransferase: identification of a selective small molecule inhibitor. Chem Biol 2010, 17(5):471-482.

23. Goodman $\mathrm{RH}$, Smolik S: CBP/p300 in cell growth, transformation, and development. Genes Dev 2000, 14(13):1553-1577.

24. Bandyopadhyay D, Okan NA, Bales E, Nascimento L, Cole PA, Medrano EE: Down-regulation of p300/CBP histone acetyltransferase activates a senescence checkpoint in human melanocytes. Cancer Res 2002, 62(21):6231-6239.

25. Santer FR, Hoschele PP, Oh SJ, Erb HH, Bouchal J, Cavarretta IT, Parson W, Meyers DJ, Cole PA, Culig Z: Inhibition of the acetyltransferases p300 and CBP reveals a targetable function for p300 in the survival and invasion pathways of prostate cancer cell lines. Mol Cancer Ther 2011, 10(9):1644-1655

26. Ait-Si-Ali S, Polesskaya A, Filleur S, Ferreira R, Duquet A, Robin P, Vervish A, Trouche D, Cabon F, Harel-Bellan A: CBP/p300 histone acetyl-transferase activity is important for the G1/S transition. Oncogene 2000, 19(20):2430-2437.

27. Iyer NG, Xian J, Chin SF, Bannister AJ, Daigo Y, Aparicio S, Kouzarides T, Caldas C: p300 is required for orderly G1/S transition in human cancer cells. Oncogene 2007, 26(1):21-29.

28. Yan G, Eller MS, Elm C, Larocca CA, Ryu B, Panova IP, Dancy BM, Bowers EM, Meyers D, Lareau L, Cole PA, Taverna SD, Alani RM: Selective inhibition of p300 HAT blocks cell cycle progression, induces cellular senescence, and inhibits the DNA damage response in melanoma cells. J Invest Dermatol 2013, 133(10):2444-2452.

29. Plati J, Bucur O, Khosravi-Far R: Apoptotic cell signaling in cancer progression and therapy. Integr Biol (Camb) 2011, 3(4):279-296.

30. Wong RS: Apoptosis in cancer: from pathogenesis to treatment. J Exp Clin Cancer Res 2011, 30:87.

31. Chaitanya GV, Steven AJ, Babu PP: PARP-1 cleavage fragments: signatures of cell-death proteases in neurodegeneration. Cell Commun Signal: CCS 2010, 8:31.

32. Coffey K, Blackburn TJ, Cook S, Golding BT, Griffin RJ, Hardcastle IR, Hewitt L, Huberman K, McNeill HV, Newell DR, Roche C, Ryan-Munden CA, Watson A, Robson CN: Characterisation of a Tip60 specific inhibitor, NU9056, in prostate cancer. PLoS One 2012, 7(10):e45539.

33. Wang KC, Yang YW, Liu B, Sanyal A, Corces-Zimmerman R, Chen Y, Lajoie BR, Protacio A, Flynn RA, Gupta RA, Wysocka J, Lei M, Dekker J, Helms JA,
Chang HY: A long noncoding RNA maintains active chromatin to coordinate homeotic gene expression. Nature 2011, 472(7341):120-124

34. Huang J, Teng L, Liu T, Li L, Chen D, Li F, Xu LG, Zhai Z, Shu HB: Identification of a novel serine/threonine kinase that inhibits TNF-induced NF-kappaB activation and p53-induced transcription. Biochem Biophys Res Commun 2003, 309(4):774-778.

35. Wu YH, Shih SF, Lin JY: Ricin triggers apoptotic morphological changes through caspase-3 cleavage of BAT3. J Biol Chem 2004, 279(18):19264-19275.

36. Sasaki T, Gan EC, Wakeham A, Kornbluth S, Mak TW, Okada H: HLA-B-associated transcript 3 (Bat3)/Scythe is essential for p300-mediated acetylation of p53. Gene Dev 2007, 21(7):848-861.

37. Baksh S, Tommasi S, Fenton S, Yu VC, Martins LM, Pfeifer GP, Latif F, Downward J, Neel BG: The tumor suppressor RASSF1A and MAP-1 link death receptor signaling to Bax conformational change and cell death. Mol Cell 2005, 18(6):637-650.

38. Elmore S: Apoptosis: a review of programmed cell death. Toxicol Pathol 2007, 35(4):495-516.

39. Monte M, Benetti R, Buscemi G, Sandy P, Del Sal G, Schneider C The cell cycle-regulated protein human GTSE-1 controls DNA damage-induced apoptosis by affecting p53 function. J Biol Chem 2003, 278(32):30356-30364.

40. Nicholls CD, Shields MA, Lee PW, Robbins SM, Beattie TL: UV-dependent alternative splicing uncouples p53 activity and PIG3 gene function through rapid proteolytic degradation. J Biol Chem 2004, 279(23):24171-24178.

41. Gu W, Roeder RG: Activation of p53 sequence-specific DNA binding by acetylation of the p53 C-terminal domain. Cell 1997, 90(4):595-606.

\section{Submit your next manuscript to BioMed Central and take full advantage of:}

- Convenient online submission

- Thorough peer review

- No space constraints or color figure charges

- Immediate publication on acceptance

- Inclusion in PubMed, CAS, Scopus and Google Scholar

- Research which is freely available for redistribution 